\title{
Die Föderation im Spiegel der zeitgenössischen Presse und Literatur Australiens
}

\section{Cornelia Schulze, Universität Wuppertal}

Australien, der einzige Kontinent, der zugleich ein Staat ist, ist von Europa am weitesten entfernt. Dennoch rückt der "fünfte" und kleinste Kontinent nach den Olympischen Spielen 2000 in Sydney erneut in den Blickpunkt internationaler Aufmerksamkeit. Denn dieses Jahr feiert Australien das hundertjährige Jubiläum seiner Föderation und damit seiner staatlichen Eigenständigkeit. Am 1. Januar 1901 verkündete der erste australische Premierminister, Edmund Barton, die Gründung des "Federal Commonwealth of Australia": "There is a nation for a continent, and a continent for a nation" (Voigt 2000:70). Diese euphorischen Worte konnten nicht darüber hinweg täuschen, dass es sich um eine "schwere Geburt" handelte. Selbst wenn der Zusammenschluss zu einem einheitlichen Bundesstaat längst überfällig war, ging ihm eine jahrzehntelange öffentliche Diskussion voraus.

Besonders in einer Zeit des Umbruchs spielen die Medien eine zentrale Rolle. Auch in den entscheidenden Jahren vor der Föderation hatte die Presse einen bedeutsamen Anteil an den politischen (und mentalen) Veränderungen. Der Kampf um eine eigenständige Nation, die damit verbundene Loslösung vom Mutterland sowie die Entwicklung eines nationalen Selbstverständnisses hielt aber auch Einzug in die zeitgenössische Literatur. Die meisten Literaturgeschichten Australiens beschreiben die 1890er Jahre daher als den Beginn einer neuen Epoche, in der sich "australische" Literatur von einer kolonialen zu einer nationalen Literatur mauserte (Green 1961:2).

Anhand ausgewählter Beispiele lässt sich belegen, dass die Option einer "Föderation" schon früh in den Köpfen der Menschen existierte. Als wohl populärstes Beispiel lässt sich die offizielle heutige Australische Nationalhymne "Advance Australia Fair" anführen, die von Peter Dodds McCormick etwa 1878 komponiert (und gedichtet) wurde. In der zweiten Strophe heißt es: "In joyful strains then let us sing, / Advance Australia Fair. / Beneath our radiant Southern Cross / We'll toil with hearts and hands; / To make this Commonwealth of ours / Renowned of the all the lands..." (Voigt 2000:86). Überraschenderweise wird zwei Jahrzehnte vor der Föderation diese in der Nationalhymne vorweggenommen. Dieser Nationalstolz entsprach jedoch nicht der damaligen politischen Wirklichkeit. Um die politischen sowie literarischen Entwicklungen dieser Zeit verstehen zu können, müssen die australische Verfassung und Mentalität sowie die spezifischen Bedingungen der zeitgenössischen Presse und Literatur berücksichtigt werden.

Angesichts der heutigen Politikverdrossenheit europaweit erscheint das Tauziehen um die Föderation als ein Kraftakt, an dem nicht nur einzelne Spitzenpolitiker beteiligt waren - der Premier von New South Wales, Henry Parkes, gilt als "Vater der Föderation" -, sondern auch die Bevölkerung. Anders als in Deutschland herrscht in Australien die Wahlpflicht, und tiefgreifende Entscheidungen müssen vom Volk mitgetragen werden. Das jüngste Beispiel einer gesamtaustralischen Abstimmung war das Referendum am 6. November 1999 zur Republikfrage, deren Verwirklichung zur 100-Jahrfeier des Commonwealth anvisiert wurde. Doch die Mehrheit entschied sich für die Beibehaltung der Monarchie. Voigt bringt die Haltung der Australier auf den Punkt: "Warum sollten sie [die Australier] etwas abschaffen, was zahnlos ist und mit gepuderten Perücken keinem mehr etwas zu Leide tut? Toleranz ist eben auch ein Wesenszug der Australier" (Voigt 2000:82).

\section{Das Ringen um die Föderation im zeitgenössischen öffentlichen Diskurs}

Die Diskussion um die Vor- und Nachteile der Gründung eines Nationalstaates wurde nicht nur im öffentlichen Diskurs geführt, sondern auch in der zeitgenössischen Literatur. Im auslaufenden 19. Jahrhundert spiegelte die australische Presse das sich wandelnde Nationalbewusstsein, das in den Föderationsbemühungen mündete: 
"Die 1890er Jahre werden auch als die Jahre der Metamorphose und Synthese vom britischen Gefühl und der Kolonialidentität beschrieben. Das Nationalempfinden unterlag einem beeinflussbaren Wandel [...]. So war es doch in diesem Jahrzehnt überwiegend der Kolonialnationalismus, der zwar im Rahmen der Bundesgründung diskutiert wurde, aber bewusst als traditionsbindender Faktor beibehalten werden sollte." (Leutenecker 2000:1289).

Dieser Wandel wurde vor allem durch die Darstellung und Wertung der Ereignisse in der Presse und Literatur geprägt.

\section{Australiens Presse- und Literaturbetrieb}

In der zweiten Hälfte des 19. Jahrhunderts war der Literaturbetrieb im öffentlichen Diskurs eingebettet: Da erst in den 1890er Jahren ein lokales Verlagswesen entstand, nutzten die meisten Autoren die Gelegenheit, ihre Texte als Serie in einer der zahlreichen Zeitschriften zu veröffentlichen. Dieses Medium erforderte einen ausgeprägten Sinn für den Zeitgeist. Oftmals beteiligten sich die Autoren als (Mit-) Herausgeber oder verdingten sich als freie Journalisten. ${ }^{1}$ Die erste Zeitschrift für Literatur war das Hobart Town Magazin. Entstanden im Jahr 1834 war sie Medium für Kurzgeschichten, Essays und Gedichte. In Sydney gründete James Tegg seine Literary News, in der erstmals auch Illustrationen und Karikaturen veröffentlicht wurden. Dank der besseren Produktionsbedingungen und des technischen Fortschritts entstanden ab den 1850er Jahren zahlreiche Zeitschriften; einen wahren Boom erlebten die reformorientierten 1880er Jahre.

Die natürliche Affinität zwischen (politischem) Journalismus und Literatur verdeutlicht der Sydney Bulletin, Australiens meistgelesene und einflussreichste Zeitschrift für Politik und Literatur zwischen 1880 und $1910^{2}$. Im Jahr 1880 gründeten die Journalisten John Haynes und J.F. Archibald die Wochenzeitschrift, die sich zum bedeutendsten meinungsbildenden Organ etablierte. Der Bulletin hatte eine Doppelfunktion: Zum einen diente er als politisches Sprachrohr, zum anderen bot er talentierten Schriftstellern ein Forum:

"At first it seemed much like its predecessors and contemporaries [...]. But it was politically and economically chauvinistic and satirically opposed to colonial pretentiousness. It favoured the federation of the Australian colonies [...]. Its chief effects on literature were to popularize bush life as a subject, to encourage amateurs to write, and effectively to move the literary capital of Australia from Melbourne to Sydney." (Goodwin 1988:36)

Als eine Besonderheit der Zeitschrift galt die Red Page, ein Sonderteil für Literaturkritik, der sich aus der Sammlung von Buchrezensionen, "Books of the Day" und "Book Exchange" zu einer eigenständigen Kolumne entwickelte. Der maßgebliche Einfluss des Bulletin auf das Verständnis australischer Literatur ist untrennbar mit dem verantwortlichen Herausgeber (seit 1896) der Red

\footnotetext{
${ }^{1}$ Einzelfälle literarischer Betätigung gab es schon früh: Barron Fields veröffentlichte 1819 seine Sammlung von Gedichten First Fruits of Australian Poetry. Doch erst die Gedichtanthologie Bush Ballads and Galloping Rhymes (1870) zeigte ein typisch australisches Gesicht. Einen weiteren Höhepunkt stellten die Erzählungen von Henry Lawson dar, die er z.B. in While the Billy Boils (1896) zusammenstellte. Besondere Beachtung erhielt A. B. Paterson für seine Balladen, die er in The Man of the Snowy River and other Verses (1895) der Öffentlichkeit präsentierte. Den ersten Roman in der Weltliteratur über Australien schrieb in Deutschland Therese Hubel unter dem Titel Abentheuer auf einer Reise nach Neu-Holland (1793, erst 1966 ins Englische übersetzt), den ersten Roman auf australischem Boden schrieb Henry Savery mit Quintus Servinton. Die Einwanderer-Trilogie The Fortunes of Richard Mahony (1917-1929) schrieb eine Frau unter dem Pseudonym Henry Handel Richardson, das Schicksal einer Aboriginal Frau schilderte Katherine Susannah Prichard in Coonardoo (1929). Doch erst die Verleihung des Nobelpreises für Literatur an Patrick White im Jahr 1973 brachte australischer Literatur weltweite Anerkennung (vgl. Voigt 125-6).

${ }^{2} \mathrm{Ab}$ den 1920er Jahren nahm die Monopolstellung des Bulletin ab. Nach mehreren Besitzerwechseln übernahm die Australian Consolidated Press die Zeitschrift im Jahr 1960; in den 1970 ern erschien sie primär als ein Informationsmagazin, in den 1980ern und 1990ern entwickelte sie sich zu einem Lifestyle Magazin (vgl. The Penguin Australian Encyclopaedia, p. 75).
} 
Page verbunden (vgl. Kramer 1981:11). A.G. Stephens entwickelte einen spezifischen Schreibstil und forderte diesen auch von den Autoren, die im Bulletin veröffentlichen wollten: "Its [the Bulletin's] preference was for concise, even terse, fiction, firmly based on lived experience" (Wilding 1994:xi). Da der Großteil aller Kurzgeschichten der 1890er Jahre im Bulletin erschien, wurde dieser Stil zum Credo der Nachwuchsschriftsteller. Stephens ist auch ein neues literarisches Selbstverständnis zu verdanken, da er den Vergleich mit der Literatur aus Übersee nicht scheute und das Spezifische der australischen Literatur herauszuheben wusste:

"[W]hat country can offer to writers better material than Australia? We are not yet snug in cities and hamlets, moulded by routine, regimented to a pattern. Every man who roams the Australian wilderness is a potential knight of Romance; every man who grapples with the Australian desert for a livelihood might sing a Homeric chant of victory, or listen, baffled and beaten, to an Aeschylean dirge or defeat. The marvels of the adventures are our daily common-places. The drama of the conflict between Man and Destiny is played here in a scenic setting whose novelty is full of vital suggestion for the literary artist." (Stephens zitiert in Ackland 1993:249)

Ferner ermutigte Stephens jeden Australier, die Erfahrungen des australischen Daseins literarisch zu verarbeiten. Für ihn hatte Australien das Potential, eine Nationalliteratur zu generieren. Der Kampf zwischen Mensch und wilder Natur, der jenseits der getretenen Pfade stattfand, sollte dokumentiert oder fiktionalisiert werden. Diese Auffassung glich seine editorischen Interventionen wieder aus und führte zu einer demokratischen und egalitären Redaktionspolitik. Er verschaffte Schreibenden aus dem gesamten Kontinent Gehör, und der Bulletin avancierte zur "bushman's Bible" (Wilding 1994:xi). Stephens Ruf nach einer typisch "australischen" Literatur fand bei zahlreichen zeitgenössischen Autoren Anklang, vor allem bei A.B. Paterson und Henry Lawson, die in den 1890ern eine australische Variante der Ballade entwickelten:

"Here local settings became a crucial if superficial indicator of Australianness, while writers took their lead not from European balladry, but from colonial oral tradition. It was spiced with satire and refractory attitudes towards establishment values, and coloured by a sense of suffering and hardship." (Webby 2000:77)

Die Sehnsucht nach einem nationalen Selbstverständnis erwuchs vor allem aus Australiens Entwicklung zu einem geeinten Bundesstaat. Während zuvor Lokalpatriotismus gepflegt wurde, erforderten die politischen Bemühungen um die Föderation ein Umdenken, das sich auch in den literarischen Kreisen niederschlug:

"Writers like Henry Lawson, Miles Franklin and Joseph Furphy were more interested in depicting what was 'Australian' from an insider's point of view; the Australian landscape and ideas about the Australian 'national character' moved to the foreground in fiction around the turn of the century." (Webby 2000:105)

Anhand von ausgewählten Texten soll die Föderation im Spiegel der zeitgenössischen Literatur dargestellt werden. Zunächst werden Beispiele aus der Prosa, dann aus der Lyrik angeführt.

\section{Die Darstellung der Föderation und verwandter Themen in der Prosa}

Einige der bekanntesten fiktionalen Werke der Literatur dieser Epoche stammen aus dem Jahr der Föderation, wie z.B. Henry Lawsons Sammlungen von Kurzgeschichten The Country I Come From und Joe Wilson and His Mates, Miles Franklins autobiographischer Roman My Brilliant Career, William Hays Debütroman Stifled Laughter und Roderic Quinns Lyriksammlung The Circling Hearths. Eine repräsentative Auswahl der zeitgenössischen Kurzgeschichte verschafft uns Stephens The Bulletin Story Book, eine Sammlung von Prosawerken, die zuvor im Bulletin erschienen waren. Im Vorwort entwickelt er sein Verständnis von australischer (National-)Literatur, so dass es als ein zentrales Manifest zur zeitgenössischen australischen Erzählliteratur gewertet werden kann: 
"[...] the aim has been to make an interesting book. It has not been attempted to choose the best examples of literary style. Judged by a high canon, our most talented story-writers are still only clever students of the art of writing. A mere two or three have been able to earn a living by the profession of literature, and even these have been obliged to make the perilous compromise with journalism. So the stories and sketches which follow are usually the literary dreams of men of action, or the literary realisation of things seen by wanderers. Usually they are objective, episodic, detached - branches torn from the Tree of Life, trimmed and dressed with whatever skill the writers possess (which often is not inconsiderable). In most of them still throbs the keen vitality of the parent stem: many are absolute transcripts of the Fact, copied as faithfully as the resources of language will permit." (Stephens 1978:12)

Stephens verweist zunächst auf die nationalen Differenzen zwischen australischer und europäischer Literatur. Nicht der literarische Stil sei ausschlaggebend, sondern die Lebendigkeit der Darstellung der australischen Lebenswirklichkeit. Ferner erklärt er anhand der Entstehungs- und Produktionsbedingungen, warum australische Literatur nur bedingt in Reinkultur existent und erwünscht war. Zeitgenössische Autoren finanzierten ihre literarischen Eskapaden mit journalistischen Tätigkeiten und publizierten vor allem in Zeitschriften: Kurzgeschichten, Balladen, (politische) Lyrik, Pamphlete und alle Formen des Zeitungsjournalismus dominieren das Bild des damaligen australischen Literatur- und Kulturbetriebs. Als wesentliches Qualitätsmerkmal der australischen Geschichten nennt Stephens die Unmittelbarkeit und Episodenhaftigkeit der Darstellung. Aufgrund dieser Besonderheiten sollten die ersten literarischen Gehversuche nicht im direkten Vergleich mit den literarischen Traditionen Europas verglichen werden. In seinem Essay "For Australians" (1899) vertieft Stephens dieses Argument:

"And here in Australia, we have no temples, no ashes worth the name. We have still to make the history and create the legendary associations which are such a powerful binding force in national life. [...]. What a mass of record and tradition, of song and story, of memorable life and love and death, presses behind that England! Australia is meaningless by comparison, lacking the inspiration of the past. But is it not possible to catch meaning and inspiration from the future?" (Stephens 1978:395)

Aufgrund der fehlenden (europäischen) Tradition im eigenen Land muss sich Australien auf sein schöpferisches Potential besinnen, eine Zukunft erfinden, anstatt seine Vergangenheit in Geschichtsschreibung zu verbannen. Stephens verweist auf das große Potential der Neuen Welt und fordert Nationalstolz und Heimatliebe als verbindliche Erziehungsideale. Die Zukunft der Kolonie läge in den Händen der australischen Bevölkerung, "[...] it will be the fault of the people, not the land, if it is not one of the best countries in the world to live and to die in..." (1978:396). Die Qualität einer Nation hänge nicht von der Bevölkerungsdichte ab, sondern vom individuellen Beitrag eines jeden Bürgers. Daher endet sein Essay mit dem patriotischen Aufruf an die australische Bevölkerung, sich in Selbstoptimierung zu üben:

"Yet the future of Australia [...] rests upon the character of Australia's inhabitants. If it be the pride of every Australian boy to become a better man than his father, of every Australian girl to become a better woman than her mother [...] both the individual and the nation will surely have their reward." (1978:398-9)

Zwei Jahre vor der offiziellen Geburtsstunde der Föderation ruft Stephens die australische Bevölkerung auf, eine geeinte Nation zu bilden. In seinem Essay "For Australia" (1900) betonter, dass der Zusammenschluss der Staaten zu einer eigenständigen Nation ein Abstraktum bliebe, sofern sich diese Union nicht auch in den Köpfen und Herzen vollziehe:

"The Commonwealth, as an abstract idea, may give the satisfaction of the instinct of devotion to country; it can supply a target for a hitherto unsatisfied instinct; but beyond that, as an abstract idea, it gives nothing. [...]. There is no magical quality in this union: no 
millennium is to be reached by the declaration of a Federal Act in so many chapters and so many clauses. We suppose that the Commonwealth will give us greater scope for effort, a wider field for energy; but it is always our effort, our energy." (1978:403)

Stephens identifiziert Selbstverantwortung und persönliches Engagement als zugrundeliegende Prinzipien der angestrebten Staatsform. Nur dann erbringen, so Stephens, "[will it] be possible to justify all the enthusiasm to which the establishment of the Commonwealth has given birth by proving to nearly every individual in the community that Patriotism Pays" (1978:406).

Untersucht man das Verhältnis zeitgenössischer Prosawerke zur Föderation Australiens muss bedacht werden, dass viele Texte die Föderation zwar nicht explizit nennen, jedoch in der Atmosphäre aufkeimenden Nationalismus geschrieben wurden. So setzen sich Autoren, die im Föderationsjahr selbst oder kurz zuvor/danach publizierten, auf individuelle Weise mit Fragen zur typisch australischen Nationalität, Kultur und Lebensweise auseinander. Als Beispiele für unterschiedliche Formen, Australianness darzustellen, sollten vor allem diejenigen Werke berücksichtigt werden, die sich besonderer Beliebtheit erfreuten oder im Nachhinein zu außergewöhnlichem Erfolg führten. Dazu zählen Henry Lawsons Joe Wilson and His Mates (1901), Miles Franklins My Brilliant Career (1901) und Joseph Furphys Such is Life (1903). Als Henry Lawson seine achtzehn Kurzgeschichten im Jahr 1901 veröffentlichte, hatte er sich bereits als ein bedeutender australischer Autor etabliert:

"It was certainly Lawson who established the enduring model of a laconic minimalism of language that taut with irony and repressed emotion. His portrayal of the life of the Australian bush has made him a nationalist icon; and though he spent most of his life in poverty his portrait once adorned the ten-dollar note. His writing not only expresses the feel of Australia, it also contains an argument. It emerged from that brief flowering of radical optimism in the late 1880 s and early 1890 s, a period of intense trade-union activity, of revolutionary fervour and utopian optimism." (Wilding 1994:x)

Sein Verständnis von Australianness, das sich in Kameradschaft, Klassenegalitarismus und Stoismus ausdrückt, spricht aus jeder Zeile seiner Joe Wilson Geschichten: "Lawson's stories and characters have been a major influence in the construction of that traditional 'national identity' that only the last few decades have begun to dismantle..." (Webby 2000:106). Ironischerweise schrieb Lawson diesen typisch "australischen" Roman in London, wo er sich an die Bedürfnisse seiner britischen Leserschaft anpasste, die ihm zu diesem Zeitpunkt - zumindest geographisch - näher standen als seine treuen Landsleute: "One aspect of these stories that does give them a 'colonial' flavour is what John Barnes calls, an obvious awareness of a foreign audience in Joe Wilson's explanations - an aspect of the Joe Wilson stories that some Australian readers find irritating'" (Webby 2000:106). Dennoch hat Lawsons Präsentation des australischen Buschlebens das Australienbild geprägt.

Als zweites Beispiel für die Reflexion über das eigene Nationalempfinden kann My Brilliant Career von Miles Franklin angeführt werden. Es handelt sich um den Debütroman einer sechzehnjährigen Australierin, die schon zu diesen frühen Zeitpunkt die Gunst Henry Lawsons genoss. In seinem Vorwort lobt er Franklins lebendige Präsentation des Buschlebens und verleiht dem Roman das ersehnte Qualitätssiegel der Australianness: "I don't know about the girlishly emotional parts of the book [...]; but the descriptions of bush life and scenery came startlingly, painfully real to me, and [...] as far as they are concerned, the book is true to Australia - the truest I've ever read" (Franklin 1901:v). Oberflächlich betrachtet war das positive Urteil des legendären Lawson eine Ehre für die junge Schriftstellerin, doch es beinhaltet auch chauvinistische Tendenzen, die für den Männlichkeitsethos (und der damit einhergehenden Entwertung der Weiblichkeit) Australiens zu Beginn des 20. Jahrhunderts symptomatisch sind. In Franklins Roman dient die australische Landschaft eher als Hintergrund für das Portrait einer unangepassten jungen Australierin, die bemüht ist, sich in der männlich-dominierten Gesellschaft zu behaupten. Im Verlauf des Romans entwickelt sich eine Liebesgeschichte, die unerfüllt bleiben muss. Franklin kombiniert in ihrem 
semi-autobiographischen Roman Elemente der Romance mit einer Parodie dieses Genres. Der Roman endet mit einer pathetisch-patriotischen Anerkennung der Leistungen der Australier: Die Männer bewähren sich im Ringen mit der wilden Natur, die Frauen aufgrund ihrer opferwilligen und arbeitsamen Mentalität (Kindler 1988: 781). Dieser Schlussakkord des Romans mag Lawson mit Franklins "mädchenhaftem" Interesse an den inneren Konflikten der Protagonistin versöhnt haben. Immerhin teilen Rezensent und Autorin einen sentimentalen Nationalstolz. So bekennt Sybylla: "I am proud that I am an Australian, a daughter of the Southern Cross, a child of the mighty bush" (Franklin 1901:231). Als Franklin My Brilliant Career im Jahr der Föderation veröffentlichte, traf sie den Nerv einer im Wandel begriffenen Gesellschaft, die sich mit Blick auf die Vereinigung nach einer verbindlichen Definition von Australianness sehnte.

Als drittes Beispiel für zeitgenössische Prosa bietet sich Such is Life (1903) von Joseph Furphy an. Furphys Hauptwerk verdankte seine Veröffentlichung dem persönlichen Einsatz von A.G. Stephens. Trotz dieser einflussreichen Protektion fand der experimentelle Roman bei den zeitgenössischen Lesern zunächst wenig Beachtung. Erst allmählich erkannte man die Bedeutung des Buches, das heute als "one of the great masterpieces and challenges of Australian literature" gilt (Webby 108). Besonders auffällig ist der fragmentarische, sprachreflektorische Schreibstil mit zahlreichen literarischen Anleihen, der Elemente des postmodernen Erzählens antizipiert. Die Konzeption und Ausführung von Such is Life zeigt Furphys bewusste Ablehnung des australischen Abenteuerromans in der literarischen Tradition von Henry Kingsley oder Rolf Boldrewood. Such is Life gilt somit als "significant for the part it played in turning Australian fiction away from the colonial romance" (Wilde et al. 1985:305). Furphy zeigt auch keine Berührungsängste mit dem literarischen Erbe Englands: er integriert zahlreiche Shakespeare- und Bibelzitate und macht parodistische Anspielungen auf den viktorianischen Roman. Der Zeitpunkt der Veröffentlichung war insofern gut gewählt, als Furphys aggressiv-nationaler Ton die Stimmung reflektierte, aus der Australien als unabhängige Nation zwei Jahre zuvor hervorgegangen war.

Grundsätzlich zeigen die besprochenen Prosawerke die intensive Suche der Autoren nach typisch "australischen" Themen und Ausdrucksformen und transportieren die Atmosphäre aufkeimenden Nationalbewusstseins. Seit der 1890er Jahre stand nicht die Vermittlung eines Australienbildes an Nicht-Australier im Vordergrund, sondern das Schaffen eines nationalen Selbstverständnisses. Je "australischer" ein Werk auf Kritiker und Leser wirkte, desto enthusiastischer fielen die Werturteile aus.

Im Gegensatz zur Prosa, in der die Föderation nicht direkt zur Sprache kam, findet man in der zeitgenössischen Lyrik zahlreiche Anspielungen auf die Föderationsbemühungen. Zudem hatte Lyrik in der utilitaristischen Gesellschaft Australiens einen relativ geringen Stellenwert, so dass aktuelle Bezüge zur australischen Wirklichkeit eine qualitative Aufwertung erzielten. Im Folgenden sollen Beispiele aus der zeitgenössischen Lyrik vorgestellt werden, in denen die Vor- und Nachteile der Föderation diskutiert wurden. Denn der Ruf nach politischer und literarischer Selbstständigkeit der 1890er Jahre kulminierte in der Entstehung populärer Balladen und satirischer Gedichte, die das wachsende Nationalbewusstsein reflektierten und daran beteiligt waren, eine gemeinsame nationale Identität zu formen (vgl. Webby 2000:74ff).

\section{Die Darstellung der Föderation und verwandter Themen in der Lyrik}

W.T. Goodge zählt zu den prominenteren Gegnern der Föderation. Norman Lindsay bezeichnete ihn als "one of Australia's best writers of light verse" (Wilde et al 301). Im Jahr 1899 publizierte Goodge seine Anthologie Hits! Skits! And Jingles!, eine Sammlung komischer Gedichte, die von skurrilen oder tragik-komischen Buschpersönlichkeiten bevölkert sind. In seinem satirischen Gedicht "Federation" karikiert er die Föderationsbemühungen als ein populistisches Unternehmen mit zweifelhaftem Ausgang:

Let us sing of Federation

('T is the theme of every cult)

And the joyful expectation 
Of its ultimate result. [...].

We shall drink to desperation,

And be quite the soberest nation

We'll be desperately loyal

Unto everything that's royal,

And be ultra-democratic

In a matter most emphatic.

We'll be prosperous and easeful,

And pre-eminently peaceful,

And we'll take our proper station

As a military nation! [...].

Hier fungiert Goodge als Sprachrohr der Gegner des Federation movements, da er die gängigen Bedenken artikuliert. Im Mittelpunkt der Kritik steht die angestrebte Verfassung mit ihrer sonderbaren Mischung aus der britischen parlamentarischen Regierungsweise und dem USamerikanischen Föderalismus. Während Befürworter der Föderation die Verbindung von Integration und Gleichheit bei gleichzeitiger Wahrung der Eigenständigkeit der einzelnen Kolonien lobten, fürchteten andere paradox anmutende Konsequenzen: Australien sollte zwar aus seiner kolonialen Abhängigkeit befreit werden, doch die britische Krone würde das offizielle Staatsoberhaupt bleiben. So könne die verfassungsmäßige Verbindung zu Großbritannien kaum dazu beitragen, die Nabelschnur zum Mutterland endgültig zu durchtrennen. Das Gedicht endet mit der Vorhersage:

\section{We'll adopt all fads and fictions \\ And their mass of contradictions \\ If all hopes are consummated \\ When Australia's federated; \\ For the Federation speeches \\ This one solid moral teach us - \\ That a pile of paradoxes are expected to result!}

(Murray 1986:;67)

Mit ironischem Augenzwinkern sagt Goodge die euphorischen Worte der politischen Redner zu Ehren der Föderation voraus. Das Gedicht endet mit dem eindringlichen Appell an den Leser, nicht in den Gesang auf die Föderation einzustimmen, sondern kritische Distanz zu der politischen Rhetorik einzuhalten. ${ }^{3}$

Im Folgenden werden Beispiele von Autoren lyrischer Werke angeführt, die sich offiziell für eine gesamtaustralische Nation einsetzten. Als imposante Gegenstimme zu Goodge kann A.B. Paterson angeführt werden. Auch er ist ein Beispiel für die Verquickung literarischen und journalistischen Schreibens. Er war Herausgeber der Sydney Evening News und des Australian Town and Country Journal sowie des Sydney Sportsman. Paterson gilt als der herausragendste Volksdichter Australiens, dessen Vision des pastoralen Australien (Australian Arcadia) in seinen berühmten Balladen entwickelt und verbreitet wurde. Seine erste Monographie, The Man from Snowy River and Other Verses (1895), war innerhalb einer Woche ausverkauft. Mit seinem "Waltzing Matilda" erschuf er nicht nur das bekannteste australische Nationallied, sondern auch einen musikalischen Exportartikel. Ähnlich wie Furphy kreierte er in seinen Werken ein ganzes Arsenal australischer Volkshelden. Er gehörte zu der wachsenden Gruppe radikaler Nationalisten der 1890er Jahre, die sich für ein geeintes, starkes Australien einsetzte. Patersons Vielseitigkeit und schillernde Persönlichkeit erlaubte ihm eine enorme Medienwirksamkeit und Präsenz im zeitgenössischen öffentlichen Leben. Sein Gedicht, "Song of the Federation", schrieb er zu Ehren der australischen Föderation. Das geeinte Australien wird darin als wunderschöne Frau beschrieben: "She was

\footnotetext{
${ }^{3}$ Goodge könnte auf den Premier von New South Wales, Henry Parkes, angespielt haben, der im Jahr 1889 eine mitreißende Rede zugunsten einer nationalen Regierung für den gesamten Kontinent hielt (vgl. Voigt 2ßBß:70).
} 
beautiful as morning,/With the bloom of the roses on her mouth, / Like a young queen lavishly adorning/Her charms with the splendours of the South" (Paterson 1946:183-4). Trotz dieser Idealisierung dringen auch skeptische Untertöne durch, da die Föderation Kind des Kalten Krieges war: "As the nations sat together, grimly waiting- / The fierce and ancient nations battle-scarred- / Grown grey in their lusting and their hating, / Ever armed and ever ready keeping guard, / Through the tumult of their warlike preparation / And the half-stiffed clamour of the drums / Came a voice crying, 'Lo, a new-made Nation, / To her place in the sisterhood she comes!'" (1946:183-4). Es gehörte zur zeitgenössischen Propaganda radikaler Nationalisten, dass Australien trotz seiner geringen Bevölkerung eine machtvolle Nation werden könne, da die Australier im Ringen mit der unzähmbaren Natur eine robuste Mentalität erworben hätten. Bevölkerungsstärkere Nationen, so das Argument, könnten auf diese innere Stärke nicht zurückgreifen, auch wenn sie schon viele Kriege geführt haben mögen: "Hark, and ye shall hear my children singing / Their war-song in countries far away. / They are strangers to the tumult of the battle, / They are few, but their hearts are very strong, / Twas but yesterday they called unto the cattle, / But they now sing Australia's marching song" (1946:184). Mit diesem kämpferischen Ton fing Paterson den radikalen Patriotismus seiner Zeit ein.

Ein weiterer Befürworter der Föderation war William Gay, aus dessen Feder die bekannten Gedichte "Australian Infelix," "Australian Federation" und "Australia 1894" stammen, mit denen er der Föderation seine geistige Unterstützung zusagt. Im ersteren beklagt er die immer wieder fehlschlagenden Bemühungen, die einzelnen Kolonien zu einem Nationalstaat zu vereinen. So zeigt er seine wachsende Ungeduld: "How long, O Lord, shall this, my country, be / A nation of the dead? / How long shall /They / Who seek their own and live but for the day, / My country hinder from her destiny?" (Gay 1911:102). In seinen Augen verhindert die egoistische Politik der einzelnen Kolonien das Entstehen einer machtvollen Nation. Erst als solche könne sich Australien aus seinem selbstverschuldeten Unglück befreien. Er bittet Gott um Unterstützung bei dem Unterfangen, die Lokalpatrioten zum Schweigen zu bringen, damit Australien endlich den Status einer eigenständigen Nation erhält. In seinem Gedicht "Australian Federation" argumentiert Gay für eine Föderation:

From all division let our land be free,

For God has made her one: complete she lies

Within the unbroken circle of the skies, And round her indivisible the sea

Breaks on her single shore; while only we,

Her foster children, bound with sacred ties

Of one dear blood, one storied enterprise,

Are negligent of her integrity.-

Her seamless garment, at her Mammon's nod,

With hands unfilial we have basely rent, With petty variance our souls are spent,

And ancient kinship under foot is trod:

$O$ let us rise, united, penitent,

And be one people, - mighty, serving God!

(Gay 1911:103)

In diesem Gedicht präsentiert Gay Australien als ein vollkommenes Werk Gottes. Erst die europäischen Bewohner hätten den Kontinent in einzelne Kolonialstaaten zerstückelt. Gay sieht es als die moralische Pflicht des australischen Volkes, das Land wieder in seinen ursprünglichen, von Gott gewollten Zustand zu versetzen. So beschwört er am Ende des Gedichts eine Nation, ein Volk herauf. In "Australia 1894" personifiziert Gay Australien als Königin, die mit kritischem Blick Zwietracht und Vereinzelung in ihrem Reich entdeckt: "Yet as she gazes o'er the plains that 
lie/Fruitful about her throne, she sighs full / sore / To see the barriers Greed has builded high, / Dividing them who brothers were before, / When still they dwelt beneath a sterner / sky / And heard the thunders of a wilder / shore" (1911:114). Durch Menschenhand und aufgrund von Raffgier wurden Zäune errichtet, wo zuvor ein einziges Land existierte. Dieses Mal verweist Gay auch auf Gefahren von außen, denen nur eine starke Nation etwas entgegenzusetzen habe. Ähnlich wie Paterson leitet er die Bedeutsamkeit eines geeinten Australien aus innerer wie außenpolitischer Notwendigkeit ab.

Edward Dyson, geboren 1865 in Victoria, zählte ebenfalls zu den Befürwortern der Föderation. Als unkonventionelles Vorwort stellte er sein Gedicht "Australia" an den Anfang seines Gedichtbands 'Hello Soldier!' Khaki Verse (1919) und räumte ihm so einen Ehrenplatz ein. Die sieben Strophen des Gedichts sind in Form eines Dialogs des Sprechers mit Australien konzipiert. Anfangs bemerkt das lyrische Ich anerkennend, dass Australien aus einer Art Koma erstanden zu sein scheint: "Australia [...]. You've done some rousing things of late, / That lift you from the simple state / In which you chose to vegetate" (Dyson 1919:3). Doch dann drückt Dyson die Notwendigkeit aus, dass sich Australien aus der imperialistischen Umklammerung befreien muss, um tatsächlich selbständig zu werden: "At length you need no sort of crutch, / You stand alone, you've voted 'much' - / Get busy and behave as such" (1919:3). England und andere Nationen hätten den neuen Status Australiens längst erkannt: "You've given all the world to know / Your proper standing as a foe, / And hats are off, and rightly so" (1919:3). Ungeduldig fordert er Beweise ein, an denen erkennbar ist, dass Australien "flügge" geworden ist: "Now have you proved it to your own?" (1919:3). Eindringlich fordert er Australien auf, die nagenden Selbstzweifel endgültig zu überwinden. Die letzte Strophe ist die Krönung des Gedichts mit starkem Appellcharakter:

Australia, life your royal brow,

And have the courage of the pride,

Audacity becomes you now,

Be splendidly self-satisfied.

No land from lowliness and dearth

Has won to eminence on earth

That was not conscious of its worth.

Nur der Wandel von der veralteten Kolonialidentität zu offen bekundetem Nationalstolz kann die "schlafende Prinzessin" erwecken. Eigenverantwortung scheint der Schlüssel, da Australien nicht im klassischen Sinn durch einen "Kuss" erweckt werden kann, sondern sich selbst erschaffen muss.

Ein weiterer Repräsentant herausragender australischer Lyrik mit patriotischem Grundton ist John Farrell. In dem von der Zeitung Sydney Morning Herold publizierten A Century of Journalism wird Farrell zusammen mit Henry Lawson und A.B. Paterson aufgeführt, da die Werke dieser Autoren als besonders "australisch" bezeichnet werden können: "The work of each is Australian to the core" (Tearle 1971:147). Farrell neigte dazu, australische Politik und Geschichte in seine lyrischen Werke hineinzutragen. Beispielsweise schrieb er zu Ehren von Queen Victorias Diamantenem Jubiläum im Jahr 1897 die Ode "Ave Imperatrix". Zur Geburtsstunde der Föderation sang ein Chor aus tausend Stimmen Farrells "The Hymn of the Commonwealth". Thema der Hymne ist die Bruderschaft zwischen den einzelnen australischen Staaten und ihre gemeinsame Zukunft als vereinte Nation. Er erkannte jedoch, dass die einzelnen Kolonialstaaten nicht einfach zusammenwachsen würden und verwies in seinem Gedicht "Gone Wrong" auf das fehlende nationale Zusammengehörigkeitsgefühl:

Alas! We still are states at heart -

Our chief desires are still the same.

We swaggered in the better part,

Then lapsed, to play the same old game

For keeps; to do the best we can

For our own gain, by force or stealth - 


\section{Ourselves before our fellow-man \\ Our wealth before Our Commonwealth.}

Farrell macht eine Beobachtung, die noch über Jahrzehnte nach Ausrufen der Föderation Geltung hatte. Er selbst fühlte sich Australien gegenüber zutiefst verpflichtet. Als aus Anlass des hundertjährigen europäischen Besiedelung Australiens der Picturesque Atlas of Australasia (1888) publiziert wurde, schrieb er sein wohl berühmtestes Gedicht "Australia," das auch in der Föderationsausgabe des Daily Telegraph erschien. Es endet mit den Zeilen:

O dear and fair! awakened from thy sleeping

So late! The world is breaking into noon;

The eyes that all the morn were dim with weeping

Smile through the tears that will cease dropping soon!

Thine have no tears in them for olden sorrow,

Thou hast no heartache for a ruined past;

From bright to-day to many a bright to-morrow

Shall be thy way, O first of lands and last!

(beide Gedichte zitiert in Tearle 1971:154)

Ähnlich wie in den vorherigen Beispielen wird Australien als "Sleeping Beauty" dargestellt, die gerade erst erwacht ist. Seine koloniale Vergangenheit und die fehlende Nationalidentität können überwunden werden, sofern es gelingt, sich von nostalgischen Gedanken zu befreien. Hier spielt Farrell wieder auf die Schwierigkeiten vieler Australier an, sich von ihrem provinziellen Lokalpatriotismus zu befreien und Australien als eine geeinte Nation zu verstehen, für die es sich zu engagieren lohnt. Seine Fähigkeit, Australien in seiner Ganzheit zu begreifen und zu vermitteln, beeindruckte auch Arthur W. Jose, den Herausgeber der History of Australasia (1913), der Farrells "Australia" und "Australia To England" zum "high water mark of our patriotic song" zählt (zitiert in Tearle 1971:154). Farrell versuchte wie einige seiner Zeitgenossen, Australien auf dem schwierigen Weg in die staatliche (und vor allem psychologische) Eigenständigkeit zu unterstützen.

Für viele Befürworter der Föderation Australiens war die Möglichkeit der Selbstgestaltung des Landes der motivierendste Grund, sich in den 1890er Jahren verstärkt für eine vereinte Nation einzusetzen. Der Begriff "Föderation" wurde zu einem Synonym für nationale Selbstbestimmung und die aktive Beteiligung Australiens auf der Schaubühne der Welt. So mauserte sich Australien von einer ehemaligen Strafkolonie zu einer unabhängigen Nation. Im Zeichen der fortschreitenden Globalisierung kommt Australien im 21. Jahrhundert wieder eine veränderte geopolitische Rolle zu. Es wird lohnenswert sein, die australische Presse und Literatur daraufhin zu untersuchen, ob und auf welche Weise sich Australien im öffentlichen Diskurs als "global player" präsentieren wird.

\section{Bibliographie}

Ackland, Michael, Hrsg., 1993. The Penguin book of $19^{\text {th }}$ century Australian literature. Melbourne: Penguin.

Dawson, Sarah, Hsg., 1990. The Penguin Australian encyclopaedia. Melbourne: Penguin.

Dyson, Edward, 1919. 'Hello Soldier!' khaki verse. Melbourne: Alex. M'Kingley.

Franklin, Miles, 1901. My brilliant career. Sydney: Angus \& Robertson.

Gay, William, 1911. The complete poetical works of William Gay. Melbourne: Thomas Lothian.

Green, H.M., 1961. A history of Australian literature pure and applied. Bde. I \& II. Sydney: Angus \& Robertson.

Goodwin, Ken. 1988. A history of Australian literature. London: Macmillan Education.

Kindlers neues Literaturlexikon, 1988, hsg. von Walter Jens, München: Kindler. [Band 5]

Kramer, Leonie, Hsg., 1981. The Oxford history of Australian literature. Melbourne: OUP. 
Leutenecker, Gerd, 2000. "Die 1790er, 1890er und 1990er Jahre: Australien an drei Jahrhundertschwellen." in: Rudolph Bader, Hsg., Australien auf dem Weg ins 21. Jahrhundert: Bilanzen -Standortbestimmungen - Visionen. Tübingen: Stauffenburg Verlag. 119-142.

Murray, Les, Hrsg., 1986. The new Oxford book of Australian verse. Melbourne: OUP.

Paterson, A.B., $1946^{13}$. The collected verse of A. B. Paterson. Sydney: Angus \& Robertson.

Stephens, A.G., 1978. A.G. Stephens : Selected writings. Hrsg. Leon Cantrell. Melbourne: Angus \& Robertson.

Tearle, Sheila, B.T. Dowd, 1971. John Farrell: poet, patriot and journalist, Journal of the Royal Australian Historical Society. 57(2 ). 143-159.

Voigt, Johannes H., 2000. Australien. München: C.H. Beck'sche Verlagsbuchhandlung.

Webby, Elizabeth, Hrsg., 2000. The Cambridge companion to Australian literature. CUP.

Wilberforce, A., C. Jose, H.J. Carter, Hrsg., 1925. The Australian encyclopaedia. Bd. I. Melbourne: Angus \& Robertson.

Wilde, W.H., J. Hooton, B. Andrews, Hsg., 1985. The Oxford companion to Australian literature. Melbourne: OUP.

Wilding, Michael, 1994. The Oxford book of Australian short stories. Melbourne: OUP. 